\title{
PREZYDENT W SYSTEMIE WŁADZY WYKONAWCZEJ REPUBLIKI CZECZENII ${ }^{1}$
}

\section{Republika Czeczenii w latach 1991-2015. Tło społeczno-polityczne}

Wydarzenia, mające miejsce na terytorium ZSRR w 1991 roku, były konsekwencją splotu czynników politycznych, społecznych i gospodarczych. Początek lat 90. dowiódł, że pozornie silne struktury polityczne ulegają bardzo intensywnej i błyskawicznej degeneracji. Prawidłowość ta szczególnie dynamicznie ujawniła się na terytoriach o skomplikowanej strukturze etnicznej i religijnej. We wspomnianym okresie doszło do intensywnej multiplikacji konfliktów politycznych motywowanych determinantami etnicznymi i gospodarczymi. Na terytorium Federacji Rosyjskiej, sukcesorki Imperium Rosyjskiego, najbardziej dramatyczne wydarzenia rozegrały się w jej kaukaskiej części - Republice Czeczenii². Najważniejsze wydarzenia polityczne, mające w latach 1990-2014 miejsce na terytorium tej republiki można podzielić na 3 główne etapy:

1) 1990-1994 - etap suwerenizacji i rozwoju tendencji niepodległościowych

2) 1994-2000 - etap wojen, quasi-niepodległości i powstawania alternatywnych form państwowości

3) od 2000 - inicjacja procesów stabilizacyjnych i wdrażanie polityki „czeczenizacji”, włączenie w orbitę parapaństwowej struktury globalnych

W 1990 roku rozpoczął pracę Ogólnonarodowy Kongres Narodu Czeczeńskiego, rok później ogłosił on „Deklarację o proklamowaniu suwerenności Republiki Czeczeńskiej Nochczi-Czo". Te działania otworzyły drogę do intensywnych prac nad kształtem ustrojowym nowego państwa, legitymizowanego przez wynik

\footnotetext{
1 Praca powstała w wyniku realizacji projektu badawczego o nr UMO-2014/12/S/HS5/00370 finansowanego ze środków Narodowego Centrum Nauki.

2 P. Grochmalski, Elity polityczne Czeczenii: historia i współczesność, (w:) T. Bodio (red.), Kaukaz: mechanizmy legitymizacji i funkcjonowania elit politycznych, t. VII, Warszawa 2012, s. 268.
} 
wyborów prezydenckich i parlamentarnych oraz uchwalenie w 1992 roku Konstytucji Czeczeńskiej Republiki Iczkerii. Konsekwencją tych działań było wprowadzenie przez prezydenta Federacji Rosyjskiej Borysa Jelcyna stanu wyjątkowego na terytorium Czeczenii oraz zaniechanie przez Czeczenię podpisania w dniu 31 marca 1992 roku układu federacyjnego. W 1994 roku wojska rosyjskie wkroczyły do Czeczenii w celu ,przywracania porządku konstytucyjnego"3. Otwarty konflikt zbrojny zakończyło zawarte w 1996 roku porozumienie w Chasaw- Jurcie, wówczas na terytorium republiki rozpoczął się trzyletni okres quasi - niepodległości, podczas którego władze Czeczenii próbowały uzyskać (na podstawie wyników wyborów parlamentarnych i prezydenckich) legitymację do sprawowania władzy. Mimo że instytucje państwa próbowały przywrócić na terytorium Czeczenii względną stabilizację, niepodległe państwo czeczeńskie istniało już tylko teoretycznie- mnożyły się konkurencyjne wobec władzy centralnej ośrodki przywództwa, intensyfikował się proces reislamizacji i destrukcji gospodarczej. Pod hasłem likwidacji terroryzmu, jesienią 1999 roku, rozpoczęła się II wojna czeczeńska. Jej efektem było ogłoszenie w czerwcu 2000 roku przejścia od otwartego konfliktu zbrojnego do działań stabilizacyjnych, konstruujących nowe cywilne instytucje republiki, wspieranych przez rosyjskie siły zbrojne alokowane na terytorium Czeczenii. W czeczeńskiej przestrzeni publicznej coraz częściej się posługiwano się hasłem „,normalizacji”’.

Obserwacja drogi, którą przebyła przez ćwierć wieku Czeczenia pozwala na przedstawienie interesujących wniosków, konstruujących pozaustrojowe tło towarzyszące powołaniu i rozwojowi instytucji prezydenta tej republiki. Do 1990 Czeczenia ${ }^{5}$ była jedną z największych kaukaskich republik, charakteryzował ją demograficzne stały wzrost ludności: w roku 1959 zamieszkiwało ją 710424 osób a w 1989 - 1275 513. Od początku lat 90. liczba ludności zaczęła spadać6, według oficjalnych danych w 1995 roku wyniosła tylko 865100 osób, by w pierwszej dekadzie XXI wieku ponownie zacząc rosnąć - stan na 1 sierpnia 2015 to 1384100 mieszkańców8. Dane te jednak należy traktować z dużą ostrożnością, bowiem ogólnorosyjski spis ludności przeprowadzony w 2002 roku może zawierać informacje celowo zniekształcane przez mieszkańców republiki ${ }^{9}$. W analogicznym okresie wzrósł również współczynnik dzietności, by w 2013 roku wynieść 3,4 $(2,8 \mathrm{w} 1991 \mathrm{roku})^{10}$. Dodatni przyrost naturalny ma swoje odzwierciedlenie także

3 M. Berowski, Federalizm rosyjski a Czeczenia w Federacji Rosyjskiej, (w:) P. Timofiejuk, A. Wierzbicki, E. Zieliński (red.), Narody i nacjonalizm w Federacji Rosyjskiej, Warszawa 2004, s. 188.

P. Grochmalski, Elity Czeczenii i Inguszetii - spór o koncepcję państwowości, (w:) T. Bodio (red.), Kaukaz Północny: elity władzy i życie polityczne, t. IX, Warszawa 2014, s. 288. Do 1991 roku jako Czeczeńsko-Inguska Autonomiczna Socjalistyczna Republika Radziecka. http://demoscope.ru/weekly/ssp/rus89_reg1.php (data dostępu: 15.09.2015 r.).

T. Grabowski, Demograficzne źródła konfliktu na Kaukazie Północnym, „Przegląd geopolityczny” 2014, nr 7, s. 101.

8 http://chechenstat.gks.ru/wps/wcm/connect/rosstat_ts/chechenstat/ru/statistics/population/ (data dostępu: 15.09.2015 r.).

9 http://demoscope.ru/weekly/2005/0211/tema01.php (data dostępu: 15.09.2015 r.).

10 http://www.gks.ru/ (data dostępu: 15.09.2015 r.). 
w piramidzie wiekowej mieszkańców, ponad 30\% mieszkańców republiki to dzieci, poniżej 10\% ludności jest w wieku poprodukcyjnym ${ }^{11}$. Ta atypowa struktura demograficzna determinuje szereg problemów związanych z rynkiem pracy, w 2014 roku z grupy osób aktywnych zawodowo stanowiącej 73,9\% ogółu mieszkańców, 21,5\% było bezrobotnych ${ }^{12}$. Średnia płaca w lipcu 2015 roku wynosiła 21594 rubli $^{13}$, jednak 34,5\% pracowników zarabia poniżej 9000 rubli $^{14}$. Bilans migracji za 2014 rok jest ujemny, z oficjalnych danych wynika, ze z Czeczenii wyjechało ponad 20000 osób, z czego prawie 12000 opuściło granice Federacji Rosyjskiej ${ }^{15}$. Znacząco zmodyfikowała się również struktura etniczna republiki: w 1989 roku prawie co trzeci jej mieszkaniec był Rosjaninem, natomiast dziś na tym terytorium jest ich ok. 3\% ${ }^{16}$. Czeczenia nie jest więc już republiką wieloetniczną, stopniowo przestaje ją także cechować bilingwizm, język czeczeński bowiem awansował do sfery komunikacji publicznej. Oczywiście kluczowe dla utrzymania tej tendencji są dwa zjawiska: odpływ ludności rosyjskojęzycznej oraz używanie języka czeczeńskiego do komunikacji politycznej ${ }^{17}$.

\section{Formalno-prawna legitymizacja instytucji prezydenta w systemie władzy wykonawczej Republiki Czeczenii}

W myśl Konstytucji Czeczeńskiej Republiki Iczkerii przyjętej 12 marca 1992 roku, pozycja prezydenta była pochodną wyboru demokratycznego kierunku rozwoju ustroju państwa, wyraźnie ciążącego ku parlamentaryzmowi ${ }^{18}$. Pozycjonowanie w Konstytucji artykułów dotyczących systemu władzy ustawodawczej i wykonawczej jednoznacznie wskazuje na silniejszą pozycję parlamentu. Akt nadawał parlamentowi nawet uprawnienia podejmowania decyzji o zdjęciu Prezydenta Republiki Czeczeńskiej ze stanowiska (art. 62). Zaznaczyć należy, że w przyjętej w dniu 12 grudnia 1993 roku Konstytucji Federacji Rosyjskiej, w art. 77 zapisano, że podmioty Federacji Rosyjskiej samodzielnie ustanawiają system organów władzy państwowej, przy czym przebiegać ma to w zgodzie z podstawami ustroju konstytucyjnego Federacji. Doświadczenia wojen i trudności z ustabilizowaniem sytuacji społeczno-politycznej w Czeczenii, zmusiły rosyjskie władze centralne do wdroże-

\footnotetext{
11 http://www.gks.ru/bgd/regl/b03_13/lssWWW.exe/Stg/d010/i010700r.htm (data dostępu: 15.09.2015 r.).

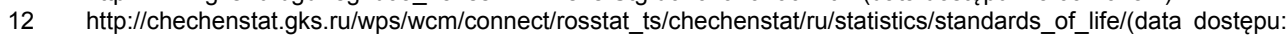
15.09.2015 r.).

$13 \mathrm{http}: / /$ chechenstat.gks.ru/wps/wcm/connect/rosstat_ts/chechenstat/ru/statistics/standards_of_life/ (data dostępu: 15.09.2015 r.).

14 http://www.gazeta.ru/business/2013/10/30/5729677.shtml (data dostępu: 15.09.2015 r.).

15 http://chechenstat.gks.ru/wps/wcm/connect/rosstat_ts/chechenstat/ru/statistics/population/ (data dostępu: 15.09.2015 r.).

http://chechnyatoday.com/content/view/4011 (data dostępu: 15.09 .2015 r.).

A. Wierzbicki, Rosja. Etniczność i polityka, Warszawa 2011, s. 175.

K. Le Roy, Ch. Saunders, Legislative, Executive, and Judicial Governance in Federal Countries, Montreal 2006, s. $237-238$.
} 
nia korekty kursu wobec kaukaskiej tej republiki. Podwaliny pod budowę nowych struktur państwowych dały dwa dekrety Prezydenta Federacji Rosyjskiej. Pierwszy - Dekret Prezydenta Federacji Rosyjskiej z dnia 8 czerwca 2000 roku „O organizacji tymczasowego systemu władzy wykonawczej w Czeczenii” umożliwił doraźną prawną legitymizację prorosyjskiego przywództwa państwowego, drugi - Dekret Prezydenta Federacji Rosyjskiej z 19 stycznia 2001 roku „O systemie organów władzy wykonawczej Republiki Czeczeńskiej”, projektował struktury władzy wykonawczej i proponował szereg rozwiązań, uwzględnionych następnie w przyjętej 23 marca 2003 roku Konstytucji Republiki Czeczenii ${ }^{19}$. Konstytucja ta w Rozdziale 4., art. 63 ustala, iż głową Republiki Czeczenii jest stojący na czele władzy wykonawczej szef rządu. 31 października 2006 roku przyjęto nową regulację w tym zakresie - Ustawę konstytucyjną Republiki Czeczeńskiej „O systemie organów władzy wykonawczej Republiki Czeczeńskiej”, która w art. 2 definiuje:

- zadania organów wykonawczych Czeczenii

- strukturę władzy wykonawczej

- kompetencje i uprawnienia władzy wykonawczej, jej prawa i obowiązki

Rozdział 2. tego aktu prawnego opisuje strukturę, status i uprawnienia organów władzy wykonawczej Czeczenii. Art. 8 w tym rozdziale wymienia wśród organów władzy wykonawczej (obok szefa republiki i rządu republiki) Administrację Szefa Republiki, której głównymi zadaniami są: stworzenie warunków umożliwiających głowie państwa wypełnianie obowiązków oraz monitoring właściwej komunikacji zarówno z instytucjami parlamentu, samorządu, sceną partyjną, jak i organizacjami pozarządowymi (również międzynarodowymi) obecnymi w Czeczenii. Administracja odpowiada również za kontakty z władzami federalnymi ${ }^{20}$. W myśl art. 9 Głowa Republiki jest najważniejszym jej urzędnikiem i zwierzchnikiem władzy wykonawczej. To ona określa i tworzy strukturę organów wykonawczych władzy państwowej, za zgodą Parlamentu Republiki Czeczenii powołuje i zwalnia z urzędów: premiera Czeczenii, jego zastępcę i ministrów rządu, którym kieruje. Do prerogatyw prezydenta należy również powoływanie szefów Administracji oraz przewodniczących i zastępców innych organów wykonawczych Czeczenii. Do zadań przywódcy państwa należą także gwarantowanie realizacji interesów mniejszości narodowych, zamieszkujących terytorium Czeczenii poprzez ich reprezentację we władzy wykonawczej oraz kontrola zgodności aktów prawnych rządu Czeczenii z prawodawstwem rosyjskim.

W wyborach prezydenckich w latach 2007 i 2011 kandydaturę Ramzana Kadyrowa zgłaszali prezydenci Federacji Rosyjskiej (Władimir Putin i Dmitrij Miedwie-

J. Szukalski, Konstytucyjne zasady ustroju Czeczenii w latach 1992-2000, ,Annales Universitatis Mariae Curie -Skłodowska. Sectio K, Politologia" 2014, nr 2, vol. 21, s. 39. 
diew), a zatwierdzał parlament Czeczenii. Natomiast 18 września 2016 roku mają odbyć się wybory bezpośrednie, poprzedzone prawdopodobnie okresem rządów wyznaczonego przez rosyjskiego prezydenta p.o. głowy republiki (kadencja Ramzana Kadyrowa wygasa w kwietniu 2016 roku). Istnieją istotne ograniczenia w zakresie łączenia stanowiska szefa Republiki Czeczeńskiej z innymi funkcjami. Nie może on jednocześnie być deputowanym Dumy Państwowej Zgromadzenia Federalnego Federacji Rosyjskiej, członkiem Rady Federacji Zgromadzenia Federalnego Federacji Rosyjskiej i sędzią. Nie może również piastować innych stanowisk państwowych w federalnej administracji publicznej i federalnej służbie cywilnej oraz obejmować innych urzędów publicznych w Republice Czeczenii. Zakazana również została jego płatna działalność, z wyłączeniem aktywności naukowej i twórczej.

Uprawnienia szefa Republiki Czeczeńskiej należy uznać za rozległe, w sposób bezpośredni lub pośredni jest on faktycznym, jednoosobowym koordynatorem i realizatorem społeczno-politycznego rozwoju republiki. Dla kształtu jej polityki wewnętrznej istotna jest przede wszystkim kompetencja głowy republiki, umożliwiająca jednoosobowe podejmowanie decyzji o dymisji rządu Republiki Czeczenii oraz możliwość kształtowania zaplecza politycznego, poprzez: mianowanie członków Rady bezpieczeństwa ekonomicznego i społecznego Republiki Czeczenii, wyznaczanie połowy członków Komisji Wyborczej Republiki Czeczenii, przedstawianie parlamentowi propozycji personalnych kandydatów na sędziów Sądu Konstytucyjnego Republiki Czeczeńskiej, tworzenie administracji prezydenckiej i rządowej. W obecnej sytuacji politycznej struktura władzy wykonawczej oraz relacje między władzą wykonawczą a legislatywą i jurysdykcją wyraźnie wskazują, że w Republice Czeczenii mamy do czynienia $\mathrm{z}$ autokratycznym modelem przywództwa i wszelkie prawne zabezpieczenia procedur demokratycznych istnieją wyłącznie $\mathrm{w}$ warstwie formalnej. Przewidziana w Konstytucji procedura impeachmentu (art. 71) zakładała wdrożenie jej przez Prezydenta Federacji Rosyjskiej po wyrażeniu wotum nieufności przez parlament Republiki Czeczenii lub w związku z utratą zaufania Prezydenta Federacji Rosyjskiej do Szefa Republiki Czeczenii.

Prezydent Ramzan Kadyrow z własnej inicjatywy wystąpił z wnioskiem o zmianę tytułu przywódcy Republiki Czeczenii. 2 września 2010 roku Parlament jednogłośnie zaakceptował prezydencką propozycję i od 5 marca 2011 roku lider republiki został jej Głową (Szefem) ${ }^{21}$. Docelowo tytuł prezydenta ma być zarezerwowany wyłącznie dla przywódcy państwowego Federacji Rosyjskiej. 


\section{Alternatywne formy państwowości na obszarze Kaukazu Północnego}

W ramach działań na rzecz stabilizacji turbulentnego regionu Kaukazu Północnego, władza centralna skoncentrowała swoje działania na obszarze Republiki Czeczenii ${ }^{22}$. Sukcesywnie przekazywała część swoich zadań demokratycznie legitymizowanemu reżimowi, równolegle finansując proces sanacji gospodarczej i społecznej z budżetu federalnego ${ }^{23}$. Osiągnięto stabilizację społeczną determinującą również fazę utrwalenia schematu relacji centrum - Republika Czeczenii, której podstawę stanowi akceptacja znacznego stopnia autonomii w zakresie zarządzania republiką ${ }^{24}$. Jest to jednak proces i kosztochłonny i długofalowy ${ }^{25}$. Mimo wypracowania wielu rozwiązań ustrojowych zbliżających sferę prawną do prawodawstwa rosyjskiego, równolegle dynamizacji podlegały procesy oddalające republikę od cywilizacyjnej unifikacji z centrum ${ }^{26}$. Przez prawie 25 lat dokonano faktycznej derusyfikacji republiki w obszarze jej składu etnicznego, reislamizacji i retrybaliza$\mathrm{cji}^{27}$. A pozorna stabilizacja przekształcona została w systematycznie powiększaną niezależność Republiki, opartą o system rządów autorytarnych ${ }^{28}$. W skrócie można określić to jako wypełnianie formy ustrojowej zgodnej z zasadami rosyjskiego prawodawstwa, treścią pozostającą poza sferą „rosyjskiego świata”29. W związku $\mathrm{z}$ transformacją Czeczenii w państwo monoetniczne, za logiczną fazę rozwoju politycznego tej republiki uznać należy również etnokrację ${ }^{30}$.

Zdobyta po I wojnie czeczeńskiej tymczasowa quasi-niezależności republiki utrudniła jej władzom walkę z radykalizacją licznych grup zbrojnych, kryminalizujących się i wzajemnie wobec siebie konkurencyjnych. W celu wzmocnienia pozycji ośrodka prezydenckiego, w 1999 roku obwołano Czeczenię państwem islamskim, rządzonym prawami szariatu. Między innymi ta inicjatywa dała impuls do powołania w 2007 roku pannarodowej struktury parapaństwowej - Emiratu Kaukaskiego. Zamierzeniem jego twórców było połączenie republik kaukaskich oraz Krajów Stawropolskiego i Krasnodarskiego oraz wprowadzenie prawa opartego o szariat. Omry 2, 7 i 8 pierwszego Emira Emiratu Kaukaskiego zapowiadały likwidację wszyst-

Ch. King, Widmo wolności. Historia Kaukazu, Kraków 2010, s. 208.

M. Słowikowski, Północnokaukaskie wyzwanie Rosji: nowa polityka rządu federalnego, (w:) T. Bodio (red.), Kaukaz: transformacja przywództwa i elit politycznych, t. IV, Warszawa 2012, s. 230.

К. Крылов (ред.), Кавказ 2011. Русский взгляд, Москва, 2011, с. 300-301.

M. Falkowski, Na peryferiach światowego dżihadu. Kaukaz Północny: iluzja stabilizacji, 45/2014, Warszawa, s. 7. M. Falkowski, M. Marszewski, Kaukaskie ,terytoria plemienne”. Kaukaz Północny - cywilizacyjnie obca enklawa w granicach Rosji, 4/2010, Warszawa, s. 3.

A. Wierzbicki, Rosja. Etniczność i polityka, Warszawa 2011, s. 176.

M.Słowikowski, Perspektywy federalizmu w Rosji z punktu widzenia konserwatywno-autorytarnej modernizacji rosyjskiego reżimu politycznego, ,,Federacja Rosyjska w XXI wieku: separatyzmy i ruchy odśrodkowe, migracje i napięcia etnoreligijne. Rocznik Instytutu Europy Środkowo-Wschodniej” 2014, nr 12, s. 12.

M. Falkowski, Ramzanistan. Czeczeński problem Rosji, 53/2015, Warszawa, s. 10.

A. Szabaciuk, Polityka Federacji Rosyjskiej wobec Republiki Czeczeńskiej: podstawowe uwarunkowania, założenia i próba oceny ,,Federacja Rosyjska w XXI wieku: separatyzmy i ruchy odśrodkowe, migracje i napięcia etnoreligijne. Rocznik Instytutu Europy Środkowo-Wschodniej” 2014, nr 12, s. 55. 
kich instytucji państwowych Czeczenii, natomiast omra 6 ustanowiła nową instytucję władzy wykonawczej na obszarze parapaństwa - walich wilajetów Emiratu Kaukaskiego ${ }^{31}$.

Od 2013 roku tracący na znaczeniu politycznym i militarnym Emirat Kaukaski musi konkurować na obszarze Kaukazu Północnego z globalną inicjatywą Państwa Islamskiego, którego aktywność zaowocowała powstaniem nowego Wilajatu Kaukazu. Zjawisko ponadnarodowych form parapaństwowych, alternatywnych lub równoległych wobec prawnie legitymizowanej władzy republiki Czeczenii jest przejawem politycznego i zbrojnego pozaoficjalnego życia tego regionu Federacji Rosyjskiej ${ }^{32}$. Oznacza to, że mimo kilkukrotnych prób siły między moskiewskimi politykami a Ramzanem Kadyrowem oraz pogorszenia sytuacji gospodarczej w Rosji, osiągnięte status quo ma szansę stanowić długofalowo skuteczny model autorytaryzmu legitymizowanego demokratycznie ${ }^{33}$. Potwierdzają to również próby multiplikacji modelu zarządzania Czeczenią na cały obszar Kaukazu Północnego ${ }^{34}$. Istnieje więc pokusa, aby uznać rozwiązania instytucjonalne wykorzystywane dla potrzeb zarzadzania Republiką Czeczenii - szczególnie spersonalizowanych charakter władzy wykonawczej - za uniwersalną reformę struktur republik ${ }^{35}$.

\section{BIBLIOGRAFIA}

Berowski Marek. 2004. Federalizm rosyjski a Czeczenia w Federacji Rosyjskiej. W Narody i nacjonalizm w Federacji Rosyjskiej, 175-190. Warszawa: Dom Wydawniczy ELIPSA.

Бутова Татьяна Витальевна (и другие). 2013. Управление устойчивым развитием Чеченской Республики. Монография к 95-летию Финансового университета при Правительстве РФ. Грозный.

Ferenc Jakub.2005. Świat odwraca wzrok. Czeczenia w świetle prawa i oczach świata. Toruń: Wydawnictwo Adam Marszałek.

Grochmalski Piotr. 2014. Elity Czeczenii i Inguszetii- spór o koncepcję państwowości. W Kaukaz Północny: elity władzy i życie polityczne, t. IX, 261- 289. Warszawa: Oficyna Wydawnicza ASPRA-JR.

Grochmalski Piotr. 2012. Elity polityczne Czeczenii: historia i współczesność. W Kaukaz: mechanizmy legitymizacji i funkcjonowania elit politycznych, t. VII, 267- 309. Warszawa: Oficyna Wydawnicza ASPRA-JR.

31 http://serwisemiratu.blogspot.com/p/emirat-kaukaski.html (data dostępu: 15.09.2015 r.).

32 http://www.jamestown.org/single/?tx_ttnews\%5Bswords\%5D=8fd5893941d69d0be3f378576261ae3e\&tx ttnews\%5Bany_of_the_words $\% 5 \mathrm{D}=$ kadyrov\&tx_ttnews $\% 5 B$ pointer $\% 5 \mathrm{D}=1 \& \mathrm{tx}$ _tnews $\% 5 \mathrm{Btt}$ news $\% 5 \mathrm{D}=44046 \& \mathrm{tx}$ ttnews\%5BbackPid\%5D=7\&cHash=9e3180 7 7e76ba3d310aeb16c06dd906e\#.VgLXLNLtmko (data dostępu: 15.09.2015 r.).

33 http://www.crisisgroup.org/en/regions/europe/north-caucasus/236-chechnya-the-inner-abroad.aspx (data dostępu: 15.09.2015 r.).

34 http://www.jamestown.org/single/?tx_ttnews\%5Bswords\%5D=8fd5893941d69d0be3f378576261ae3e\&tx_ttnews\%5Bany_of_the_words $\% 5 \mathrm{D}=$ kadyrov\&tx_ttnews $\% 5 \mathrm{Bpointer} \% 5 \mathrm{D}=2 \& \mathrm{tx}$ _ttnews $\% 5 \mathrm{Btt}$ news $\% 5 \mathrm{D}=43840 \& \mathrm{tx}$ ttnews\%5B backPid\%5D=7\&cHash=d49bf390be548ffe7182aa700230743e\#.VgLXatLtmko (data dostępu: 15.09.2015 r.).

J. Ferenc, Świat odwraca wzrok. Czeczenia w świetle prawa i oczach świata, Toruń 2005, s. 45. 
Крылов Константин. 2011. Кавказ. Русский взгляд. Москва.

King Charles. 2010. Widmo wolności. Historia Kaukazu. Kraków: Wydawnictwo Uniwersytetu Jagiellońskiego.

Le Roy Katy, Saunders Cheryl. 2006. Legislative, Executive, and Judicial Governance in Federal Countries, Montreal: McGill-Queen's University Press.

Słowikowski Michał. 2012. Północnokaukaskie wyzwanie Rosji: nowa polityka rządu federalnego. W Kaukaz: transformacja przywództwa i elit politycznych, t. IV, 227-258. Warszawa: Oficyna Wydawnicza ASPRA-JR.

„Stability in Russia's Chechnya and Other Regions of the North Caucasus: Recent Developments Jim Nichol Specialist in Russian and Eurasian Affairs". CRS Report for Congress, December 13, 2010 .

Szukalski Jerzy. 2014. „Konstytucyjne zasady ustroju Czeczenii w latach 1992-2000”. Annales Universitatis Mariae Curie-Skłodowska. Sectio K, Politologia, 2(21): 29-43.

Wierzbicki Andrzej. 2011. Rosja. Etniczność i polityka. Warszawa: Oficyna Wydawnicza ASPRA-JR. 


\section{THE PRESIDENT IN THE SYSTEM OF EXECUTIVE POWER OF THE REPUBLIC OF CHECHNYA}

Following the separatist declaration of independence in 1991, Russian-Chechen relations systematically deteriorated resulting in the occurrence of two open-armed conflicts involving Russian forces. From 2001 onwards a program, known as "Chechenisation", was introduced by the Russian Federation as a long-term solution to the problem. This was established on the principle of creating an authoritarian regime, at the centre of which stood a strong president with broad powers. The article discusses the issues involved and suggests that the intended solution has become seriously weakened, as evidenced by the latest reports from the North Caucasus.

Keywords: Russian Federation, Republic of Chechnya, the North Caucasus, presidential system, the president of the Chechen Republic

Słowa kluczowe: Federacja Rosyjska, Republika Czeczenii, Kaukaz Północny, system prezydencki, prezydent Republiki Czeczenii 